\title{
Parametric Study on a Caisson Based OWC Wave Energy Converting System
}

\author{
Hsien Hua Lee1, Y.-F. Chiu², C.-Y. Lin'1, C.-H. Chen', M.-H. Huang² \\ ${ }^{1}$ Department of Marine Environment and Engineering, National Sun Yat-sen University, Taiwan \\ ${ }^{2}$ Harbor and Marine Technology Center, IOT of MOCT, Taiwan \\ Email: hhlee@mail.nsysu.edu.tw
}

How to cite this paper: Lee, H.H., Chiu, Y.-F., Lin, C.-Y., Chen, C.-H. and Huang, M.-H. (2016) Parametric Study on a Caisson Based OWC Wave Energy Converting System. World Journal of Engineering and Technology, 4, 213-219.

http://dx.doi.org/10.4236/wjet.2016.43D026

Received: September 19, 2016

Accepted: October 13, 2016

Published: October 20, 2016

\begin{abstract}
This study uses a numerical method to analyze the proposed model structure. Before the parametric analysis, a pre-analysis to make sure the analytical results are accountable, a verification analysis was performed. The results found are compared well with the limited experimental findings of Goda et al. and it is very encouraging to find that for the proposed method as an alternative for green energy developments, as long as an appropriate design is performed, an OWC combined with breakwater structure may provide an alternative for green energy system utilized in a harbor area. From the results of the first stage of parameter analysis that the size of the openings of the cell of converting system is variable, a traditional full opened cell is not necessary the most efficient design for the wave power conversion in terms of the variations of air pressure inside the cell and air speed through the outlet orifice that will drive the electricity power generator.
\end{abstract}

\section{Keywords}

Breakwater Design, Wave Energy, Wave Power Converting System, Caisson Breakwater Application, OWC

\section{Introduction}

Taiwan is an island with limited energy resources but over expanding industrial development of high technology products, which causes intensive consuming requirement of electricity powers. Corresponding to the growth of the areas and numbers of industrial parks for high technology production and gradual retirement for out-of-age generators in the early built nuclear power plants, Taiwan has since faced a risk of random shortage of power supply, especially in summer seasons. In order to extend the power supply, many alternatives including new nuclear power plant and more traditional combustion 
thermo power plant have been discussed but disgusted by major publics due to the environmental influences and concerning for disastrous risks that may not be bearable for a small island like Taiwan. Therefore, the only alternative left to make up for the deficiency of power supply now is green energy system. It also becomes a policy for the government to encourage developments in the solar power and wind power electricity generation system. Even though wave power converting system is not a popular choice now, it has very good potential to play a supplemental role for the future development of green energy, especially for a remote island or villages close to coastal line.

Intensive studies for a wave-power converting system were performed during late 1980s and then 1990s, but however, a combination with breakwater system was firstly studied in Japan [1] [2]. In those advanced studies, not only experimental tests were performed but also on-site full-scale structure was built and tested. Many valuable data were acquired and some important results were concluded. Important conclusions including: the efficiency of power can be obtained from the conversion system, the estimated direct cost for a system of comparable size and scale, a range of dimensional ratio between the air chamber and the wavelength and the most important one that the combination for a breakwater with the wave-power converting system would not affect the function of the breakwater but reinforce it.

Unfortunately, even though the study from Goda et al. [1] [2] is invaluable and pioneering, it is too hard and too costly to be repeated for an on-field experiment. It is also too much confined by many local factors for a special case to apply to the caisson breakwater in other different locations. However, by following the findings of Goda et al. and the contemporary studies [3]-[7], a series of studies are being performed by adopting but upgrading a similar system, so called the caisson based OWC type wave energy converter for green energy developments. This study is focusing on the analysis of the interactions between the wave motion and the air pressure, the variations of the air flow and pressure inside the chamber of the OWC system, and in addition, the reflection coefficient in front of the breakwater is also evaluated. During the discussion, the efficiency of the converting system is evaluated when some of the parameters of the system are varied. The main parameters considered in this study include the submerged depth of the openings of the OWC system in terms of the wave height and the width of the chamber along the direction of the incident wave, which also measured in terms of the wave length as a dimensionless number.

\section{Theorem Applied in the Study}

In this study a theorem of unsteady Navier-Stokes Equations in conservation form consisting of continuity equations, equation of momentums and equation of turbulence dynamics are applied and shown as follows. The governing equations applied to this study is so called a $K-\varepsilon$ turbulent model, which is derived from the continuity equation, equation of momentum and equation of turbulence dynamic energy for incompressible fluid. Shown as following is the continuity equation for a 2-dimensional incompressible flow 


$$
\frac{\partial u}{\partial x}+\frac{\partial w}{\partial z}=0
$$

Considering the viscosity of the fluid, the equation of momentum for the $\mathrm{x}$ - and z-direction respectively, can be presented as follows,

$$
\begin{gathered}
\frac{\partial u}{\partial t}+u \frac{\partial u}{\partial x}+w \frac{\partial u}{\partial z}=-\frac{1}{\rho} \frac{\partial P}{\partial x}+v\left(\frac{\partial^{2} u}{\partial x^{2}}+\frac{\partial^{2} u}{\partial z^{2}}\right) \\
\frac{\partial w}{\partial t}+u \frac{\partial w}{\partial x}+w \frac{\partial w}{\partial z}=-\frac{1}{\rho} \frac{\partial P}{\partial z}+v\left(\frac{\partial^{2} w}{\partial x^{2}}+\frac{\partial^{2} w}{\partial z^{2}}\right)-g
\end{gathered}
$$

It is noticed that $u, w$ is the instant component of velocity of the flow in the $\mathrm{x}$ - and z-direction; $\mathrm{P}$ is the instant pressure while $\rho, v$ is the density and kinetic viscosity for the fluid. However, for the engineering practice when the turbulent flow is small, it is difficult to catch the variation and therefore, the variables in the Navier-Stoke equations will generally be replaced by an increment to the average values. Furthermore, an application of Boussinesq presumption that the relationship between Renolds stress and gradient of average velocity of the fluid is linear may yield the governing equations into a form of $K-\varepsilon$ model. $K$ is the turbulent kinetic energy and $\varepsilon$ represents the dissipation of turbulence. Presented as following is the formula for the so called $K-\varepsilon$ model.

$$
\begin{gathered}
\frac{\partial k}{\partial t}+\bar{u}_{i} \frac{\partial k}{\partial x_{i}}=\frac{\partial}{\partial x_{i}}\left[\left(v+\frac{v_{t}}{\sigma_{k}}\right) \frac{\partial k}{\partial x_{i}}\right]+G-\varepsilon \\
\frac{\partial \varepsilon}{\partial t}+\bar{u} \frac{\partial \varepsilon}{\partial x_{i}}=\frac{\partial}{\partial x_{i}}\left[\left(v+\frac{v_{t}}{\sigma_{\varepsilon}}\right) \frac{\partial \varepsilon}{\partial x_{i}}\right]+\frac{\varepsilon}{k}\left(C_{\varepsilon 1 G}-C_{\varepsilon 1} \varepsilon\right)
\end{gathered}
$$

where

$$
G=v_{t}\left(\frac{\partial \bar{u}_{i}}{\partial x_{j}}+\frac{\partial \bar{u}_{j}}{\partial x_{i}}\right) \frac{\partial \bar{u}_{i}}{\partial x_{j}}
$$

It is noted that the parameters in the equations (4) to (6) such as $C_{\mu}, C_{\varepsilon 1}, C_{\varepsilon 2}, \sigma_{k}, \sigma_{\varepsilon}$ are empirical numbers that must be obtained from experiments or on-field data analysis. Once the components of flow in perpendicular direction are determined then the value of $K, \varepsilon$ can be found and so does for the velocity of turbulent flow.

For the boundary conditions, still many equations related to the free surface of the water, boundaries between the fluid and the wall and the wave generation are needed.

\section{Design for Various Parameters}

For a typical OWC wave energy converting system, dimensions of the converting cell or the water column are always the most important factors that may affect the converting effect of the energy from the incident waves. Other than dimensions of the converting cell, shapes and openings of the cell are also important factors corresponding to the parameters of incident waves. Since this is the first step of the study, the main parameter considered in this study is the openings of the cell. Shown in Figure 1 as the following are models of a wave-power-converting system with various openings for incident 

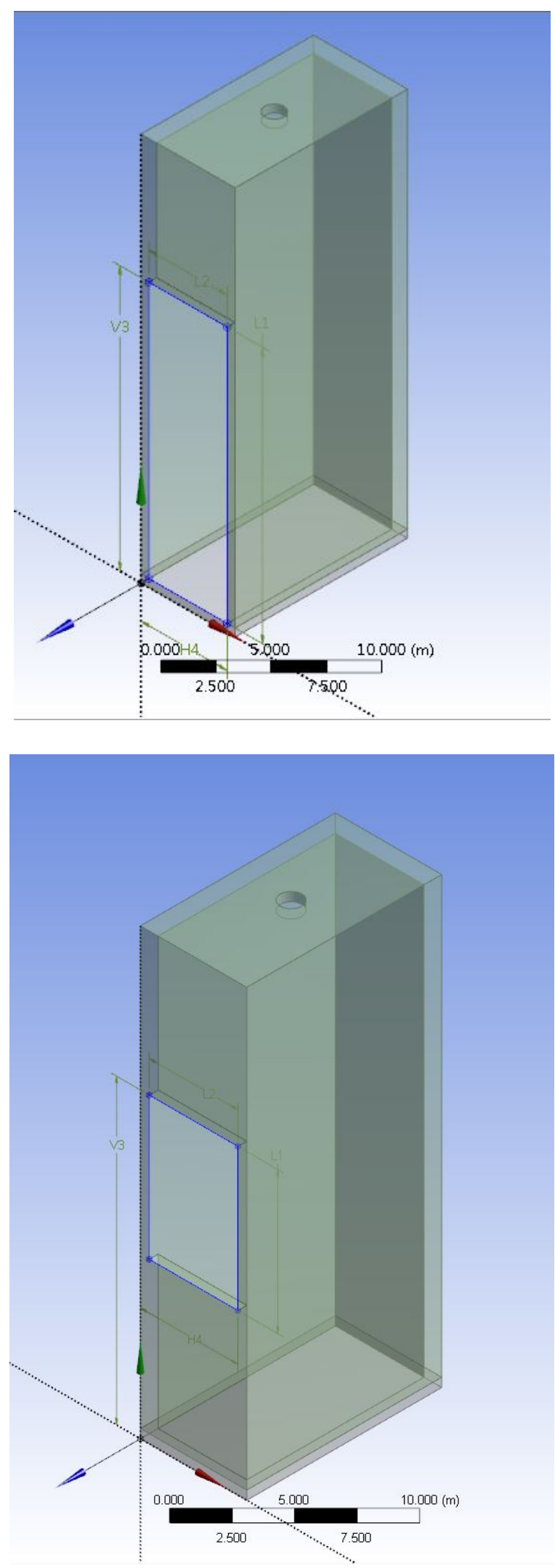

Figure 1. Schematic view for a wave-power converting system with various front openings. 
waves. The one on the left-hand side is the traditional type, which has an opening all the way to the bottom of the converting structure or the sea bed while the one on the right-hand side has an opening of limited size. Totally, three sizes of opening are proposed, namely, $100 \%, 40 \%$ and $25 \%$ proportional to the original or traditional design with full opening in the direction of incident waves.

The observation will be focused on the wave-power converting effect, which can be indicated in many variables including the wave oscillation in the cell, variation of air pressure in the cell and the flow speed through the outlet of the cell. After all, the power to be converted into electricity may be the most important indication for the converting effect. However, in this stage of research, the variation of pressure in the cell and the speed of air flow will be studied.

\section{Analytical Results}

As indicated in previous section that the major responses from the wave-power converting system include both the air pressure in the cell of the system and the speed of the air flow through the outlet on the top of the cell. Shown in Figure $\mathbf{2}$ is the variation of responses for water and air in the power-converting cell, where variations of water-height and speed variation of air-flow through the outlet orifice can be observed and the difference between inside and outside of the converting-cell is also clearly presented.

Presented in Figure 3 and Figure 4 are typical responses obtained from the analytical results including both the speed of the air-flow and the variation of pressure inside the cell. Figure 3 shows the air velocity in the cell for various period of wave. The speed is calculated as an average of the one third highest values (significant values). It is noticed that the conventional type of converting system with full opening against the
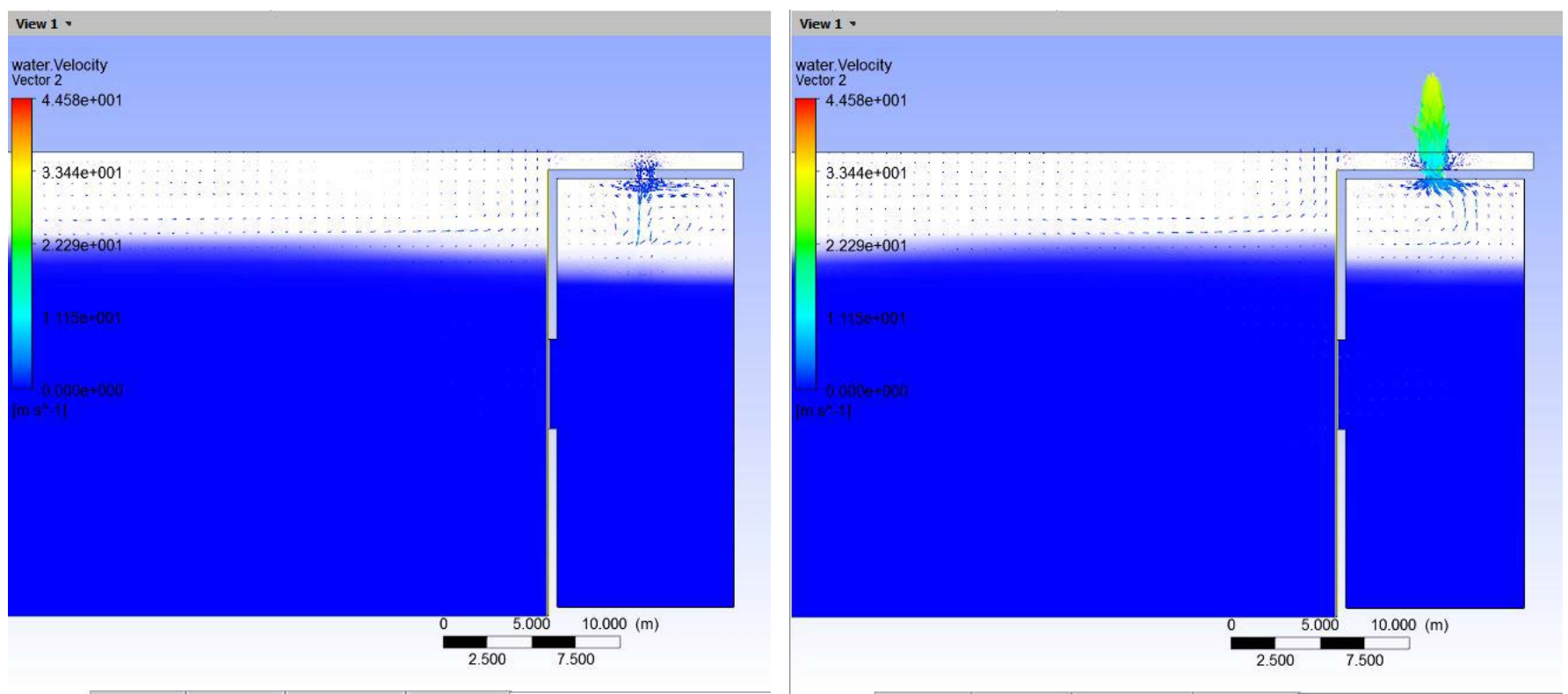

Figure 2. The variation of responses in the cell during the application of incident wave. 


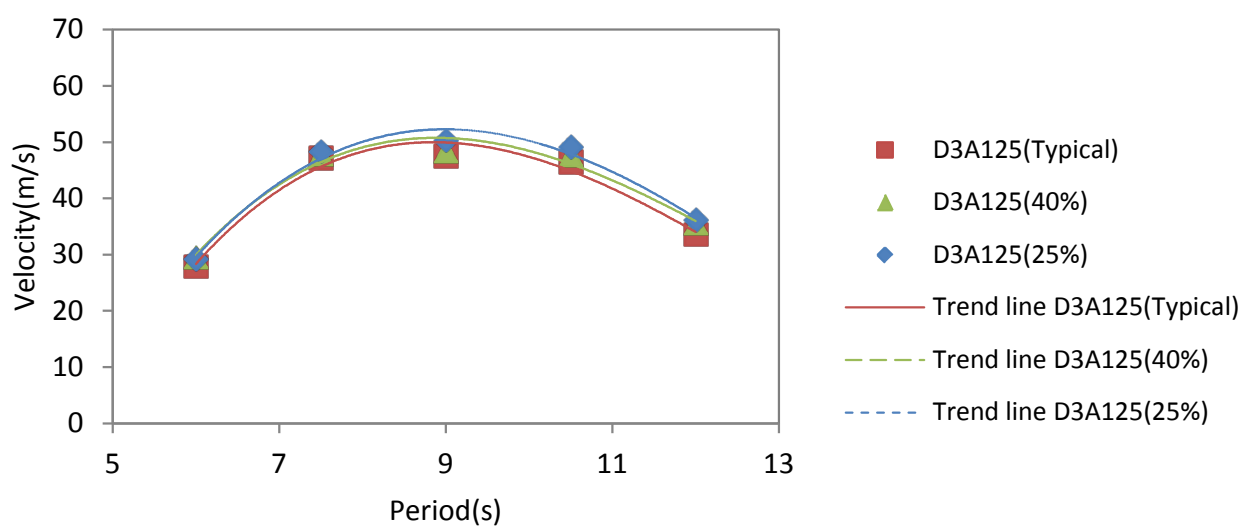

Figure 3. The air velocity (average of 1/3 maximum) in the cabinet for various period of wave.
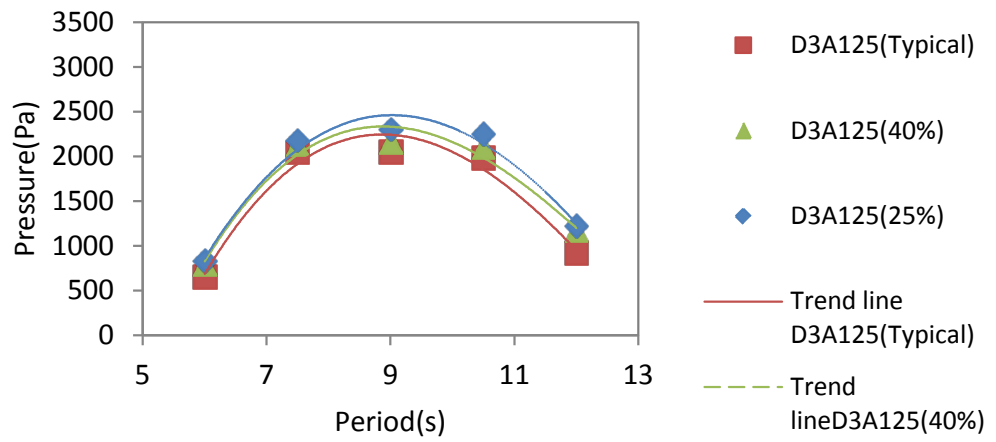

Figure 4. The air pressure (average of $1 / 3$ maximum) in the cell for various period of wave.

incident wave is not necessary to have a better performance, as seen from the figure, where in most cases of the incident wave with various periods the air speed for conventional converting system is smaller compared to the ones with smaller openings.

A similar phenomenon is also found in the results of the pressure response in the cell of the converting system as presented in Figure 4. However, when it is compared to the response of the air speed, some differences can be observed such as the variations in different periods of the incident waves and the larger difference in responses between cells with various openings. A more significant resonant response is found from the peak value at period 9 seconds of incident waves.

\section{Conclusion}

Since parameter study is a long and painful process, this study is the very first step for the parameter studies. However, from the results of the first stage of parameter analysis that the size of the openings of the cell of converting system is variable, it is found that a traditional full opened cell is not necessary the most efficient design for the wave power conversion in terms of the variations of air pressure inside the cell and air speed through the outlet orifice that will drive the electricity power generator. The performance of a OWC wave power converting system may be dependent on the parameters of the converting structure and the relationships between the structure and the envi- 
ronmental conditions, mostly related to the water depth and incident waves. Therefore, the results of this study may be treated as a special case for the design of a OWC wave converting system under certain circumstances.

\section{References}

[1] Goda, Y., Nakada, H., Ohneda, H., Suzuki, M., Takahashi, S. and Shikamori, M. (1991) Results of Field Experiment of a Wave Power Extracting Caisson Breakwater. Proceedings of Ocean Developments, 7, 143-148.

[2] Goda, Y., Shinda, T., Chiyama, S., Ohneda, H., Suzuki, M., Takahashi, S., Shikamori, M. and Takaki, Y. (1989) Experiment of a Wave Power Extracting Caisson Breakwater. Proceedings of Ocean Developments, 5, 1-6.

[3] Boccotti, P. (2005) Comparison between a U-OWC and a Conventional OWC. Ocean Engineering, 34, 799-805. http://dx.doi.org/10.1016/j.oceaneng.2006.04.005

[4] Boccotti, P. (2006) Caisson Breakwaters Embodying an OWC with a Small Opening. Part I: Theory. Ocean Engineering, in Press.

[5] Boccotti, P. (2006) Caisson Breakwaters Embodying an OWC with a Small Opening. Part II: A Small Scale Field Experiment. Ocean Engineering, in Press.

[6] Dorrell, D.G. and Hsieh, M.F. (2008) Performance of Wells Turbines for Use in Small-Scale Oscillating Water Columns, International Society of Offshore and Polar Engineering Conference, ISOPE 2008, Vancouver, July 2008.

[7] Lee, H.H. and Jeng, M.-L. (2014) Experimental Study on the Floating Type of Wave Power Converter with Guide-Piles. Ocean Engineering, in Press.

\section{Submit or recommend next manuscript to SCIRP and we will provide best service} for you:

Accepting pre-submission inquiries through Email, Facebook, LinkedIn, Twitter, etc. A wide selection of journals (inclusive of 9 subjects, more than 200 journals)

Providing 24-hour high-quality service

User-friendly online submission system

Fair and swift peer-review system

Efficient typesetting and proofreading procedure

Display of the result of downloads and visits, as well as the number of cited articles

Maximum dissemination of your research work

Submit your manuscript at: http://papersubmission.scirp.org/

Or contact wjet@scirp.org 